\title{
HEIGHTS, NUTRITION, AND WELL-BEING IN ARGENTINA, CA. 1850-1950. PRELIMINARY RESULTS *
}

RICARDO D. SALVATORE a Universidad Torcuato Di Tella

\begin{abstract}
RESUMEN
Este ensayo presenta resultados de estimaciones de estaturas medias para diversas regiones de Argentina durante el período 1850-1950. Esta evidencia, tomada de registros de reclutas y prisioneros, es utilizada para cuestionar algunas de las generalizaciones sobre el crecimiento económico argentino, basadas en datos de ingresos per-cápita y salarios. Se sostiene que, en términos de estatus nutricional y de salud, la era del progreso liberal derramó menos bienestar que el esperado. Algo similar ocurrió con el crecimiento agro-exportador de principios del siglo XX. Por el contrario, el período conocido como la "gran demora» - el período de inter-guerras - fue testigo de notables aumentos de bienestar biológico, particularmente en la década de 1930. Se sugiere también que durante la segunda guerra mundial y los primeros gobiernos peronistas, las estimaciones sobre alturas indican un retraso nutricional y de salud en el conurbano bonaerense. El ensayo presenta además datos sobre la distribución regional de las alturas, que reflejan un alto grado de desigualdad regional hacia la década de 1920.
\end{abstract}

Palabras clave: antropometría, condiciones de vida, nutrición, Argentina, siglos XIX y XX

\footnotetext{
* Received on $29^{\text {th }}$ June 2006.

a Departamento de Historia, Universidad Torenato Di Tella. Sede Miñones, Miñones 2177, Buenos Aires C1428 ATG, Argentina. rdsalva@utdt.edu.
} 


\begin{abstract}
This essay presents recent estimates of average heights for different regions of Argentina during the period 1850-1950. This evidence, taken from registers of prisoners and military recruits, serves to question some traditional views of Argentine economic growth based on income and wage data. The essay suggests that the era of liberal progress resulted in less welfare among the lower classes than is usually assumed. A similar situation occurred during the agrarian-export growth of the first decade of the $20^{\text {th }}$ century. In contrast, the period known as the "great delay» witnessed notable improvements in biological welfare, particularly during the 1930s. In addition, height estimates indicate that during WWII and the first Peronist administrations there was a nutritional setback in the Buenos Aires industrial belt. Data on the provincial distribution of heights for the 1920s show an important degree of regional inequality.
\end{abstract}

Keywords: anthropometric, living conditions, nutrition, Argentina $19^{\text {th }}$ and $20^{\text {th }}$ century.

JEL, Classification: I12, N36

\title{
INTRODUCTION
}

After more than two decades of continuous progress, anthropometric history - the study of heights and other bodily measures of biological well-being in a historical perspective- constitutes today an important part of economic history. Starting from the pioneering studies of Robert Fogel, Roderick Floud, John Komlos and Richard Steckel in the early $1980 \mathrm{~s}^{1}$, the discipline has grown in depth and complexity, accumulating a body of evidence, methods and questions which have enriched our understanding of the biological impact of economic development ${ }^{2}$. While initially concentrating on the United States and Great Britain, the inquiry has now acquired an international dimension. Various collections published within the last ten years have made contributions from researchers working in the five continents available, all interested in ascertaining the influence of nutrition and public health on the well-being of populations ${ }^{3}$.

\footnotetext{
1 See Steckel (1979); Floud-Wachter (1982); Margo-Steckel (1982); Fogel-EngermanTrussell (1982); Fogel (1987); and Komlos (1987).

2 For narratives of the evolution of anthropometric history, see Steckel (1995) and (1998); Komlos (1989) chap.1; and Komlos-Baten (2004).

3 See, for example, Komlos ed. (1995); Steckel-Floud eds. (1997); and Komlos-Baten eds. (1998).
} 
Anthropometric studies have used average heights as a robust indicator of the biological component of human welfare. Average stature measures "net nutrition", a stock of accumulated bodily energy reserved for growth. Each addition to this stock is formed by the intake of nutrients minus the claims on this energy for bodily maintenance, work and disease ${ }^{4}$. While genetics play a role at the individual level, on aggregate its influence is minimal ${ }^{5}$. Most scholars attribute the changes in average stature to two major components: nutrition and health. Work intensity appears as a third factor, conditioning bodily needs for energy and reducing the body's resistance to disease ${ }^{6}$.

Average height has been recommended as a good substitute for income measures (real wages, national per-capita income and per-capita consumption) during time periods or for areas in which these indicators are unavailable. For contemporary (post WWII) economies, scholars have found a significant correlation between the log of per-capita income and average heights (Steckel 1995). It has been suggested that average height could be used for estimating income levels in the past ${ }^{7}$. Such backward projections can be dangerous, as increases in real wages, income or consumption were not always accompanied by increases in mean stature or body mass ${ }^{8}$. Scholars have also resorted to heights to measure social and regional inequality, using either estimates of average height by socio-economic condition or the coefficient of variation of the height distribution ${ }^{9}$.

One of the advantages of average height as a measure of well-being is its sensitivity to changing conditions of income distribution, work intensity and public health. This is due, to a great extent, to the existence of height data at the individual and local level. Income indicators present information that can rarely account for individual differences and local circumstances. One of the limitations of average height is also its greatest advantage. More often than not, height data refer to populations in the lower strata of society, simply because the sources of such data are usually prisons, armies, hospitals and poor-houses. However, there are also sources which indicate the height and body mass of elite children and adults (military schools, insurance company records). In short,

${ }^{4}$ See Komlos (1989), chap.1; and Steckel (1995).

5 Komlos-Lauderdale (2007).

6 While Komlos prefers a nutritional interpretation of the two most important puzzles in anthropometric history (Komlos 1996), other authors have focused on the importance of disease. See Fogel (1994); Voth-Leunig (1996); and Coelho-McGuire (2000).

7 Coll (1998); and Brinkman-Drukker-Slot (1988).

8 Here the "Antebellum puzzle,» where rapid growth was accompanied by an important fall in stature, appears as the leading case. However, similar anomalies have been found in industrializing Sweden, the Habsburg empire, the British Isles and $18^{\text {th }}$ century Bavaria. Komlos (1987, 1989 and 1996); Baten (2000).

9 See Baten (2000); Guntapalli-Baten (2006); Bassino (2006). 
anthropometric measures bring more variation to our estimates of welfare, particularly in the geographical and social dimensions.

As corrected measurements of per-capita consumption and family real wages claim to represent «economic welfare», average stature is one of the best and most comprehensive indicators of the «biological standard of living ${ }^{10}$. Separating the factors influencing health and nutrition during infancy from those variations resulting from puberty and adolescence has proven difficult. Youths who had suffered stunting during infancy can recover part of the potential growth lost during the second growth spurt. This possibility makes it hard to interpret the meaning of adult average heights. Conventionally, anthropometric historians present height data in birth cohorts, attributing 21 years of growth to the birth year. This simplification is justified in the belief that an important proportion of growth is attained in the first three years of life. Further study of the «catch-up» process in a historical perspective is crucial to further our understanding of the value of adult heights as a measure of human welfare ${ }^{11}$.

Perhaps the most important advantage of mean heights in relation to economic indicators of welfare is the disaggregated nature of the information. Height data can be determined at the district level or even, provided a sufficient number of cases is available, at the level of cities or towns. To this extent, heights provides a closer picture of the spatial dispersion of living standards. This feature makes stature particularly appropriate for studies of spatial or regional convergence or divergence in the long-run ${ }^{12}$. Mean stature could be profitably used in connection with life expectancy. For populations at the peak of their productive years, life expectancy (at age 20 or age 25) appears to be an appropriate complementary measure. This indicator assigns greater weight to the influence of chronic disease in the later years of life ${ }^{13}$. Average stature is a measure that combines adequately the impact of disease and nutrition in the body of infants and adolescents, but says little of adults' well-being during the rest of the life-cycle ${ }^{14}$.

${ }^{10}$ For a clear distinction between biological and consumer welfare, see Komlos and Baten (1998).

11 The pioneering study of the catch-up growth experienced by slave children in the US South during the Antebellum period (Steckel 1979) was not a typical case. Studies of family distribution of nutrients have failed to find a similar dramatic transition between people who suffered deprivation in infancy but were well-fed during adolescence.

12 At best, convergence studies based upon wage data indicate how certain cities or industries catch up with each other but, except for notable exceptions, do not show a process of spatial convergence in a true sense.

13 When measured at ages $0-1$ or $0-3$, life expectancy reflects mostly the impact of mortality caused by infectious disease, malnutrition and poor conditions of hygiene.

${ }_{14}$ In principle, excessive work during childhood appears detrimental to the process of growth. This factor, however, has not been isolated and its influence has yet to be measured appropriately. 
The «human capabilities» approach, pioneered by A. Sen, has shown the importance of using schooling rates and crude rates of literacy in measuring welfare ${ }^{15}$. In general, the ability to acquire and process information makes individuals perform better in labor markets and protect their overall health more. However, it has been difficult to identify the true relationship between human capital and net nutrition ${ }^{16}$. Better educated people tend to be taller as a result of «social difference». Families with higher incomes can provide not only better nutrition for their children, but also better education. By keeping children at school, higherincome families also keep them away from work, an important deterrent of growth. To children of working-class families, artisanal training or elementary instruction gives adolescents an advantage in the labor market, making catch-up growth possible.

In Argentina, few authors had worked with stature from a historical perspective. Earlier studies (Peralta 1922 and López 1948) aimed at evaluating the biological condition of the «Argentine race» as a product of the immigration wave. These contributions were full of concerns about race and inheritance which are no longer part of the agenda of anthropometric history. Available anthropometric studies of aboriginal populations, generally based upon small samples, prevent solid inferences about the health and nutrition of these populations ${ }^{17}$. Modern anthropometric history in Argentina is in its infancy. This article is an attempt to summarize the main results of recent research into the biological well-being of Argentines between 1850 and $1950^{18}$. The emphasis is placed upon the long-term, using fragmentary series to generate a composite view of major trends and shifts in net nutrition. It is important to identify the periods in which the health-nutrition status of Argentines, particularly those in the lowest tiers of the socio-occupational scale, deteriorated and the periods in which they improved. It is also crucial to grasp the regional dimensions of biological welfare in relation to the alleged convergence of income due to national integration of labor and commodity markets. The persistence of economic inequality and its impact upon net nutrition has been an important dimension of my research. Education, social difference, region of origin and occupation are

\footnotetext{
15 See Sen (1985).

16 Malnutrition in early childhood, as has been proven for Ghana, delays school enrollment. Glewwe-Jacoby (1995).

17 B. Bogin and Keep (1998) used these anthropometric studies by physical anthropologists to suggest a plausible long-term trend in the evolution of heights of indigenous «Latin Americans».

${ }_{18}$ The estimates correspond to populations spread over territories of different spatial boundaries and with different social characteristics. This limits the possibilities of comparisons between periods and samples.
} 
crucial variables which seem to have influenced the long-term evolution of biological welfare in Argentina.

\section{THE LATE COLONIAL AND POST-INDEPENDENCE PERIODS}

A collection of 8,000 military recruitment papers or filiaciones, including soldiers of various wars, allowed us to estimate heights for the late colonial and the early post-independence period ${ }^{19}$. During this period there were changes in recruitment methods. While the battalions of the wars of independence consisted mainly of volunteers and «rescued» slaves, in the 1830s and 1840s the army resorted to drafting "vagrants» and other delinquents. In the 1850s, the regular army completed its forces with hired men. There were also changes in the social origins of the soldiery. The farmers who joined the armies of the wars of independence were gradually replaced by landless rural laborers and people without an occupation. Compared with the battalions of the 1850s, mostly manned with natives of the Pampa region and European immigrants, the regiments of the independence period enlisted natives from all provinces of the former Viceroyalty of Rio de la Plata.

While some caution is required when drawing inferences from these data ${ }^{20}$, the sample does provide an assessment of well-being for a period in which there is no evidence about national income and the information about wages is patchy and scattered. Estimated average height suggests notable changes in net nutrition in the territory of the Viceroyalty of Rio de la Plata. Soldiers' stature decreased during most of the period 1782/87 to $1802 / 06$. The lowest point in stature was reached in 1802-1806, a period in which harvest failures coincided with the closing of international trade. Starting somewhere between 1807 and 1811, average stature began to increase, reaching a plateau in the period 1827-1831. Subsequently, stature rose significantly into the late 1830 s.

It is possible to identify two distinct phases: one of absolute decrease in stature during the late colonial period; another of rapid recovery of stature during the post-independence period ${ }^{21}$. The crisis of the late colonial period, leading to a situation of food scarcity and unemploy-

\footnotetext{
19 The sample included soldiers of the wars of independence as well as soldiers of the national army rebuilt after Rosas' defeat in the battle of Caseros (1852). A smaller group of soldiers represented those who defended the United Provinces of Rio de la Plata during the war with Brazil (1825-1828). See Salvatore-Baten (1998).

20 Truncation problems associated with changing minimum height requirements created additional difficulties in the estimation of the trend. We used the Komlos \& Kim method in order to obtain standardized means (Salvatore y Baten 1998).

21 Between these periods, during 1805-1809, the limited number of observations prevents a reliable estimate.
} 
ment in 1803-04 has been studied by historians ${ }^{22}$. The improvement in health and nutrition in the early independent period, instead, appears to be a novelty. Generally, the contrary has been assumed: that the wars of independence caused a sharp fall in income due to the destruction of harvests and roads, the deviation of resources away from consumption and investment and the uncertainty and social disorder caused by frequent changes in government ${ }^{23}$. Our evidence suggests the need to revise this interpretation ${ }^{24}$.

The decline in stature in the late colonial period could be associated with the failure of the Bourbon reforms, the instability of imported food supplies due to the Napoleonic wars and the increased marginalization of creoles by the Spanish administration. The Río de la Plata suffered an increase in the price of wheat between 1798 and $1805^{25}$. The increase in the meat supply (a byproduct of rising exports of hides) did not help, for the poor could hardly substitute meat for bread. In the absence of a poor relief system and with recurrent interruptions in trade affecting employment and farming, the poorer became poorer.

In the post-independence period, institutional reforms, freer markets, military mobilization and population movements contributed to improve the biological standard of living. The wars of independence were perhaps less demanding on the peasant economy and less disruptive of internal commerce than historians have traditionally assumed. Freer trade, particularly after 1815 , permitted the importation of food at affordable prices: flour from the United States, sugar and farinha from Brazil, dry goods from Spain and Italy ${ }^{26}$. After 1820 the expansion of cattle ranching in the southern frontier increased the supply of beef to the city, as well as the supply of hides, jerked beef and tallow to export markets ${ }^{27}$. The import of cheap European textiles alleviated workers' budgets while contributing to improved hygiene ${ }^{28}$.

The transition from the late colonial to the post-independence period brought about important changes in the distribution of nutrients and

22 The food crisis of 1802-1805 in Potosí has been examined by E. Tandeter (1991). The same is less clear for the Rio de la Plata region.

23 See, for instance, Coatsworth 1993: 7.

${ }^{24}$ We estimate a growth in stature of 2.6 to 2.9 centimeters between $1782-87$ and 1837 41 (birth period with a two-year lead). The estimated absolute height of these soldiers is less reliable than their change over time. Statures of the order of 158 to 160 centimeters are quite low for farmers and laborers living on a diet rich in protein.

25 Garavaglia (1995).

${ }^{26}$ In the 1820 s farmers complained about the cheap competition of imported flour from the US.

27 See Amaral (1998).

28 Minor sanitation reforms during the Rivadavia administration (mid-1820s) were followed by vaccination campaigns against smallpox in the 1830 s. 
health among social groups and regions. The geographical distribution of well-being in the 1820s and 1830s was more egalitarian than in the 1920s. Remarkably, the soldiers from the central provinces were as tall as those from the Littoral, while soldiers born in the Northwest were taller than those born in Buenos Aires. Soldiers classified as trigueños (sun-burned mestizos) gained stature relative to whites. Both groups fared much better than Blacks and Mulattoes, who gained only half a centimeter between the 1780 s and the 1830s. While artisans did not show significant gains in stature, farmers and peons increased 2.1 centimeters on average ${ }^{29}$. The export growth of the post-independence period did not involve a deterioration of living standards in the interior provinces. Recruits from the Northwest were as tall as those born in the Littoral. Pastoral capitalism and caudillo politics, to the extent that they allowed the ruralization of the population and the dissemination of small-scale farming, produced an improvement in living standards of the population ${ }^{30}$.

\section{PROGRESS DURING THE LIBERAL ERA (1850-1890)}

The following period, from Rosas' fall (1852) to the federal compromise of 1880 , was a period characterized by the rise to power of the liberal elite and the implementation of their vision of progress. Free immigration, rivers open to international trade, the inflow of foreign capital and modern infrastructures (railroads and ports) would help to put the natural resources of the pampas into production. The separation and conflict between Buenos Aires province and the rest of the Argentine Confederation delayed the implementation of this project for a decade ${ }^{31}$. The increased European demand for wool fostered the expansion of sheep-farming in the Buenos Aires pampas, creating «sheep fever» in the 1860 s $^{32}$. Meanwhile, the other Littoral provinces

29 Surprisingly, peons and farmers were the same height. All our estimates indicate a more egalitarian distribution of income in the post-independence period than in the late colonial period.

30 Brown (1979) and Gelman (1996) presented convincing evidence of the dissemination of small-scale farming and livestock-raising; while Amaral (1998) has shown the important role of managerial skills in the development of "pastoral capitalism». Estimates of wealth, however, continue to show the post-independence period as one of growing inequalities (Johnson 1994). For a summary of recent findings see Salvatore and Newland 2003.

31 Monetary and banking reforms as well as a new trading code gave the province of Buenos Aires new institutions to boost its economy and re-establish its connection with the world economy (Irigoin 2000; Adelman 1999).

32 Rural regions responded to the external economic stimulus with new forms of tenancy and share-cropping (Sábato 1990). 
developed agriculture with the help of European immigrants. The immigrant "colonies» in Santa Fé and Entre Ríos (ca.1870-1895) were the clearest emulation of the US model of agricultural development with small-scale firms ${ }^{33}$.

This period is crucial for an understanding of the relationship between agricultural development, export-led growth and nutrition. At this time, The Argentine Confederation was one of the most open economies in the world ${ }^{34}$. It was during this period that the country changed from net-importer into net-exporter of grain ${ }^{35}$. An important reduction of transportation costs, brought about by the expansion of railways and the opening of communal roads, allowed farmers to make grain available at ports at competitive prices ${ }^{36}$. New share-cropping contracts allowed landowners to spread the risks associated with opening new lands for sheep-raising and farming.

For this period we have two data series on stature which show contradictory trends. The first is a series of average heights of recruits residing in the city of Buenos Aires produced by Juan S. López (1950). This information presents us with an optimistic perspective on the evolution of biological well-being of urban residents. According to this data, recruits of Buenos Aires grew 2.4 centimeters in stature between 1855 and 1900 (see Figure 1). This growth indicates that the inhabitants of the city were able to counter the incidence of contagious disease with increasing real incomes ${ }^{37}$. The second series, taken from individual records of prisoners in Buenos Aires province, shows a more pessimistic assessment of biological well-being during the liberal era. According to this source, the stature of prisoners remained practically stagnant during the period 1849-51 to 1889-91. If there was a trend between 1850 and 1893, this was moderately increasing until $1870-72$ and then moderately declining through 1893 (see Figure 2).

The data on urban recruits provided by J.S. López must be interpreted with caution. This series has not been controlled by changes in sample composition or corrected by truncation. It is likely that, with increasing immigration, recruiters found themselves in a better position to select stronger and taller soldiers for the Argentine army. In compari-

\footnotetext{
33 It was in Santa Fé that a new corn-growing economy developed amidst the existing large ranches with sheep and cattle. Gallo (1984).

34 Its exports per capita outranked most contemporary national economies. See Newland (1998).

35 Cereals grew from a negligible share of exports in 1870 to 50 percent of export values in 1900. Scobie, Argentina: A City and a Nation (1964), p. 119.

36 Gallo 1984: 235.

37 Two great epidemics, yellow fever in 1871 and cholera in 1884, had a strong impact on the health of the city during this period.
} 
FIGURE 1

AVERAGE HEIGHTS OF RECRUITS, BUENOS AIRES CITY, 1855-1900

(crude means)

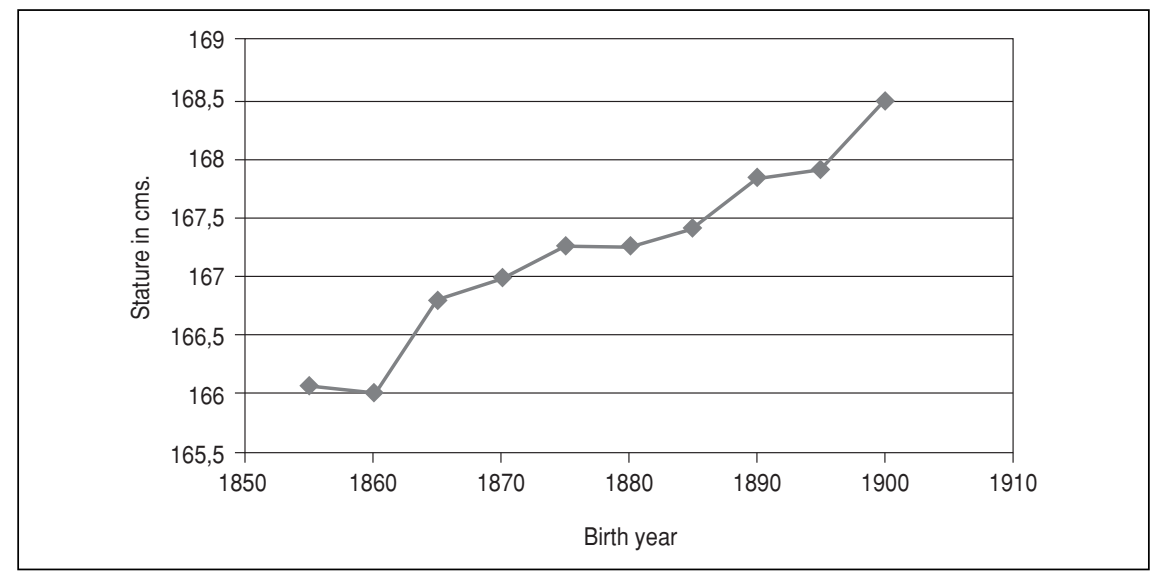

Source: J. S. López, «La estatura masculina en la ciudad de Buenos Aires» (1950).

son, the second set of data appears more reliable. It comes from the registers of two provincial prisons. The sample includes 2,785 prison inmates, 70 percent of them peons, 41 percent of them illiterate and 76 percent born in the province of Buenos Aires. Most of the prisoners were rural and belonged to the lower echelons of the working-class. According to this preliminary evidence, the inhabitants of the port-city benefited more from economic progress and institutional change than the residents of its rural hinterland. Before the "wheat revolution", which started in Santa Fé, reached Buenos Aires province (1890s onward), there was no gain in welfare for the lower classes of the latter province. Prisoners' heights also indicate the dramatic effect of the 1890 s crisis upon the net-nutrition of the inhabitants of the rural Buenos Aires regions ${ }^{38}$.

Though these estimates are still too crude, they defy conventional wisdom. Usually, this period has been presented as one of rapid progress in both institutions and the economy. Liberal politicians achieved a government based on public opinion, improvements in financial and monetary institutions, the promotion of European immigration, the

38 The failure of the 1892-93 harvest, due to a draught, led to increases in the prices of food, although it is also likely that the international crisis of 1893 impacted negatively on the country's capacity to import food items. 
FIGURE 2

STATURE OF BUENOS AIRES PRISONERS, 1840-1895

(Crude Means)

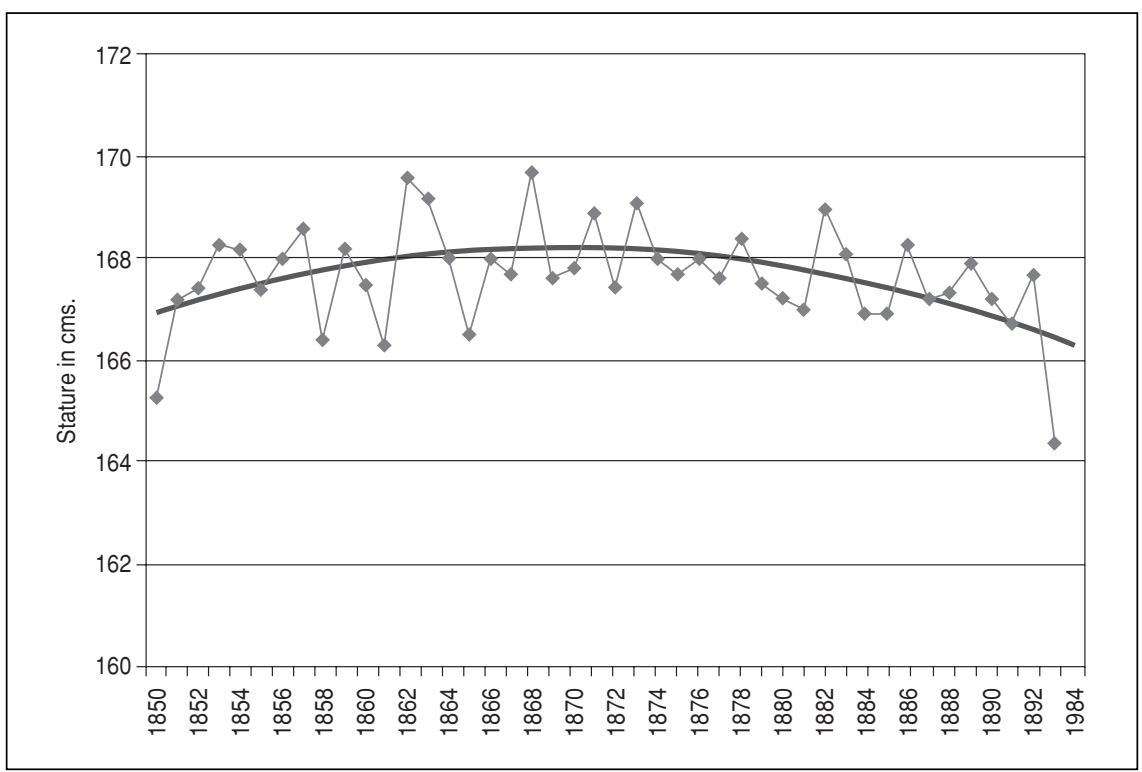

Source: Salvatore, unpublished results.

establishment of free elementary education and the expansion of the area of land used for agriculture. However, our preliminary estimates indicate that there was little or no variation in stature during most of the period 1850-1890, especially among the lower strata of the population of Buenos Aires province.

THE «GOLDEN AGE»AND THE «GREAT DELAY»

Traditionally, the period 1880-1914 has been considered a "golden age» in Argentine economic history, a time during which the country's growth rate was similar to or better than other leading economies in the world. The success of an export economy, producing beef and cereals for Europe, is generally associated with massive inflows of European immigrants and capital at a time of greater institutional stability, strong investments in infrastructures and an important expansion of the area under cultivation. WWI is usually considered the dividing line ushering in a 
period of sluggish economic performance while, for others, it is the beginning of a "great delay» before industrialization ${ }^{39}$.

New evidence about average heights of recruits and prisoners questions the conventional wisdom regarding the impact of human wellbeing on the agrarian export economy of the period 1890-1914 and of the subsequent «Great Delay» of the inter-war period (1919-1939). The first dataset comes from the registers of five prisons located in Buenos Aires province. The sample $(n=8,900)$ contains prisoners born in the province of Buenos Aires and in other provinces of the Pampa region (78 percent), in the city of Buenos Aires (10 percent) and in the interior provinces (12 percent). Most of the prisoners were literate and born in urban areas ${ }^{40}$. This data confirms the dramatic effects of the 1890-93 depression, and shows little or no progress in the biological well-being of uns-

FIGURE 3

MEAN STATURE OF PRISONERS, 1890-1940

(Standardized means, unskilled laborers)

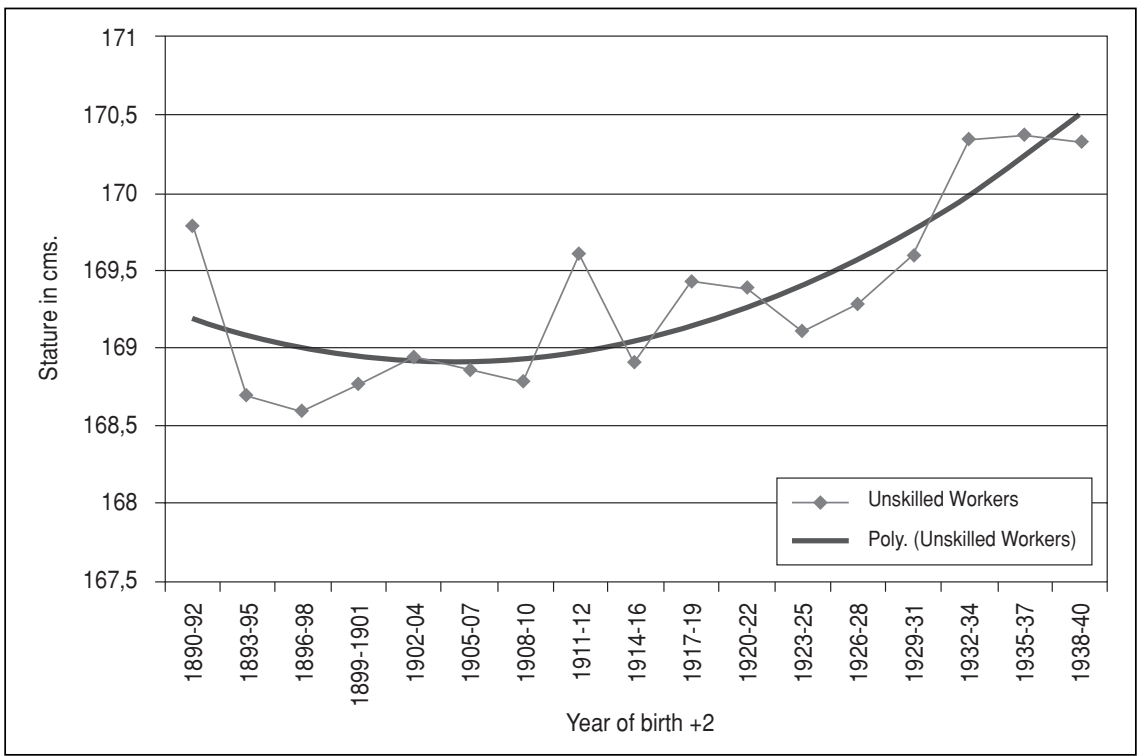

Source: Salvatore, «Biological Welfare in the Argentine Pampas».

39 See Cortés Conde (1979); Di Tella-Zymelman (1971); among others.

40 A more complete description of the dataset is provided in Salvatore (2004c). 
killed laborers until ca.1910. Only after the end of WWI can a clear and sustained upward trend in heights be observed (see Figure 3).

The second set of estimates is based on a large sample $(\mathrm{N}=22,594)$ of recruits born between 1901 and 1934, taken from the enlistment registers of the Patricios Battalion in Buenos Aires city. The sample is composed of 18-year-old recruits, 80 percent of them workers (unskilled laborers, skilled workers and employees), 56 percent born in the Pampa region, 35 percent in the interior provinces and 9 percent in the city itself. These are youths (at 18 they have not reached their adult height) whose welfare was affected by health and nutrition conditions prevailing in the country at large (Pampa and the Interior) ${ }^{41}$. During the birth cohorts 1901-1910, heights fell significantly for unskilled laborers and remained stagnant for the average of all recruits (see Figure 4). During

FIGURE 4

STATURE OF SOLDIERS OF THE PATRICIOS BATTALION, BORN 1901-1934

(Five-year averages, in centimeters)

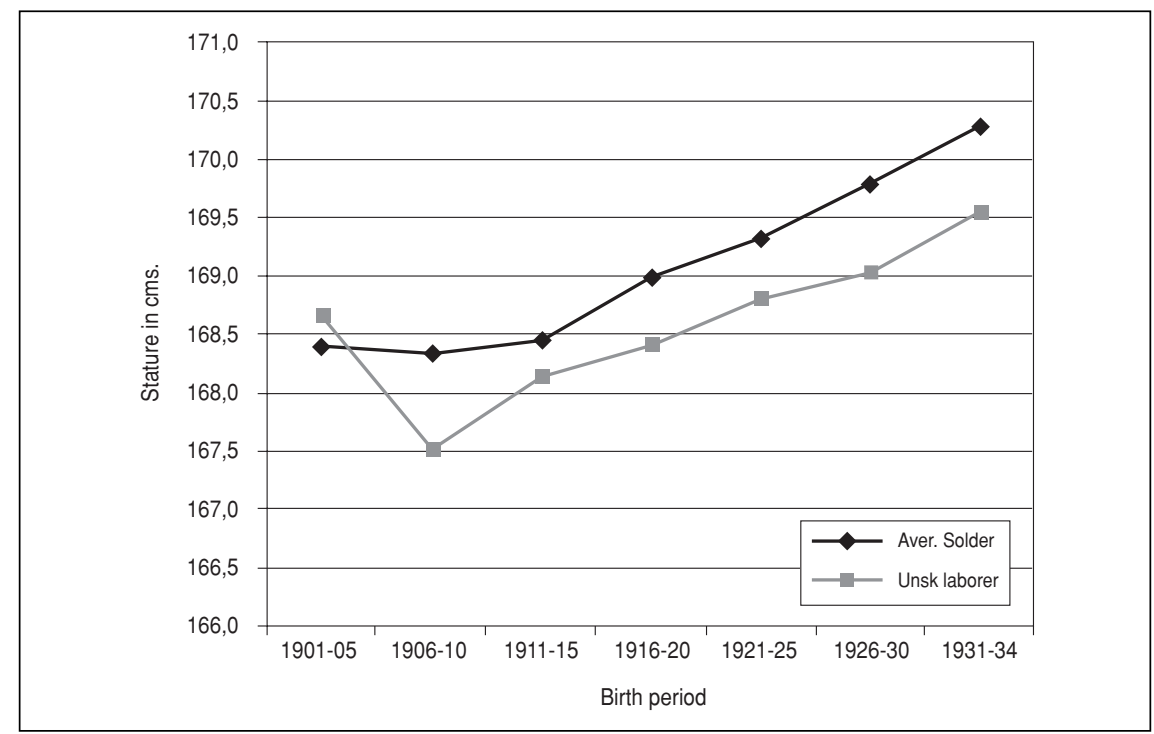

Source: Salvatore 2004a.

* average soldier $=$ weighted average of unskilled laborer, skilled worker, employee, independent producer, and students and teachers.

** both estimates are standardized means, this average refers to soldiers born in the Pampa region, in urban areas $(>2,000)$.

${ }^{41}$ Later there were opportunities for catch-up growth as their families took them to Buenos Aires city where employment opportunities and income levels were higher. 
the period 1911-1918, soldiers' stature recovered to the level attained at the turn of the century and, from the end of the WWI, soldiers' heights increased continuously until the early 1930s.

Here we see that the process of agrarian, export-led growth involved a significant "penalty» on the health and nutrition of native unskilled laborers. On average, unskilled laborers lost 1.6 centimeters in stature between 1903 and 1912. In contrast, between 1919 and 1931 there was an almost constant increase in the stature of unskilled laborers; the gains were modest ( 1.2 centimeters) but indicate that changes in income distribution, work intensity and public health compensated the slowing down of economic growth. Clearly, workers fared better during the interwar period than during the "Golden Age» ${ }^{42}$.

Workers resisted the effects of the Great Depression well. The small impact of this important external shock upon the health and nutrition of unskilled workers is remarkable. Between 1931 and 1934 unskilled workers lost 0.2 centimeters on average. The same could be said about the inflationary experience of the First World War. Except for a fall in 1917, between 1915 and 1919 workers were able to sustain and improve their health and nutrition status ${ }^{43}$. After this, estimates from prisoners and recruits coincide: the industrialization which came after the depression brought important gains in biological well-being to workers.

TABLE 1

AVERAGE HEIGHTS BY REGION OF BIRTH 1901-1934

(Recruits of «Batallón Patricios»)*

\begin{tabular}{|c|c|c|c|}
\hline Period & Pampa (1) & Interior (2) & Difference (1)-(2) \\
\hline $1901-1905$ & 167.32 & 166.70 & 0.62 \\
$1906-1910$ & 167.73 & 166.15 & 1.58 \\
$1911-1915$ & 167.75 & 166.37 & 1.34 \\
$1916-1920$ & 168.38 & 166.63 & 1.75 \\
$1921-1925$ & 168.77 & 166.95 & 1.82 \\
$1926-1930$ & 169.10 & 167.36 & 1.74 \\
$1931-1934$ & 169.65 & 167.97 & 1.68 \\
\hline
\end{tabular}

* Urban recruits, unskilled workers, 18-years old.

Pampa = born in Buenos Aires, Santa Fé, Córdoba and Entre Ríos

Interior $=$ born in the rest of the provinces

Source: Salvatore 2004a.

42 In a recent contribution (Salvatore forthcoming) I show how indexes combining different indicators of welfare present the 1920 s and 1930s as better times than the 1910s.

${ }_{43}$ Natives from the interior provinces seem to have suffered more from the inflationary impact of the First World War and its aftermath. 
Table 1 shows estimated differences between recruits born in the Pampa region and those born in the Interior. These estimates clearly show that the decline in stature between 1901-05 and 1906-10 was a phenomenon associated with the interior provinces; the Pampa region did not suffer this decline. Interior recruits were only able to recover previous levels of stature after 1920. When both regions are included, recruits show no gain in stature between period 1901-05 and 1910-15. The "Golden Age», then, appears associated with a stagnation of biological welfare which could be called "nutrition stress". This stagnation also extended to the region most favored by exportled growth: the Pampa region, where the exports of wheat and beef were produced. The gap in heights between recruits born in the Interior and those born in the Pampa region increased over time, from 1.3 centimeters between 1911-1915 to 1.7 centimeters in the period 1931-34. Agro-export development tended to accentuate existing regional differences.

If the economy showed any signs of «retardation» or «delay» during the interwar period, average stature indicates the opposite: a sustained improvement in biological welfare. Recruits born in the Pampa region gained 1.3 centimeters in height between the 1911-15 and 1926-30 birth cohorts. Those born in the Interior gained 0.6 centimeters. Though the Interior lagged behind the Pampa region, the conditions of health and nutrition improved for both regions during the interwar period ${ }^{44}$.

Recruitment data show important differences in stature associated with education, skills and occupation. Illiterate recruits were 0.7 centimeters shorter than recruits with basic reading and writing ability. Those who had modern skills were 1.3 centimeters taller than those who lacked such skills. Compared with unskilled laborers, skilled workers were 0.2 centimeters taller and clerical employees were 0.7 centimeters taller. High-school students and teachers were 2.7 centimeters taller than farm laborers. Economic growth failed to narrow the gaps separating individuals with different social and skill endowments. Between 1901-05 and 1931-35, students gained 4.3 centimeters in stature while unskilled laborers gained only 0.9 centimeters (Salvatore 2004a).

In comparison with available income data, the estimates for average height present three "puzzles» requiring examination. First: the stagnation of overall stature during the period of fastest growth in the export economy (1901-1910). Second: the sustained growth in stature during the period 1919-1934, usually regarded as a period of "growth retarda-

${ }^{44}$ When the first quinquennium of import-substitution industrialization is added, the growth in stature reaches 1.8 centimeters. 
tion». Third: the existence of only minor setbacks in stature at times of massive crises in the external sector; in particular, during the Great Depression when exports, employment and income fell dramatically (Salvatore 2004a).

Stature stagnation during the first decade of the $20^{\text {th }}$ century was probably the combined result of the pressure of mass immigration upon local wages, the high prevalence of disease among children, the widespread use of child labor and the rise in the prices of food and rent associated with the success of the export economy. Before 1914, workers bought food items at international prices, whether they were export items such as beef or wheat, or imports such as cooking oil, noodles, or wine. The children of working-class families were doubly unfortunate. They were raised in a period of rising prices of food and housing; and also in a period of massive inflow of cheap European labor. Besides exerting a downward pressure on wages, the availability of European labor prompted employers to discriminate against native (Creole) workers ${ }^{45}$. The Tenant Strike of 1907 was perhaps a good barometer of the pressure generated by mass immigration: rapidly rising rents and stagnant wages led many tenement dwellers to «strike» in demand for state regulation of housing contracts. Exporting food items had a cost for the nutrition of children of working-class families, keeping the price of food high at a time of increased competition in the labor market. The risk of disease was also an important factor. Despite the increasing influence of the hygienist movement, public health policies proved unable to reduce infant mortality rates significantly until the early $1920{ }^{46}$. Immigrants doubled the rate of growth of Buenos Aires, generating a demand for health services and sanitation facilities that the city could not provide ${ }^{47}$.

The increase in stature in the interwar period could be explained by a constellation of favorable circumstances. In part, this was the result of increasing income. Helped by increased unionization and strike activities, real wages, which had remained depressed until 1918, started to rise after the WWI, reaching turn-of-the-century levels towards 1922-25. (Salvatore 2004a) In part stature growth revealed changes in diets. The per-capita consumption of dairy products rose during this period, a symptom that working-class families chose consumer baskets more protective of children's growth. From the late 1920s onwards, the state made

\footnotetext{
45 Bialet Massé's 1904 report on the conditions of the Argentine working classes contains multiple examples of these discriminatory employment practices.

${ }^{46}$ This was true for the city of Buenos Aires. The sharp decline in infant mortality came two or three decades later in the Interior.

47 Immigrant societies tried to cope with some of the more basic demands but could not substitute the state in areas such as sewage and clean water see, Baily (1999).
} 
important efforts to control child labor ${ }^{48}$, while public health policies in the most important cities became more effective.

Two important external shocks, the First World War and the Great Depression, had a limited impact upon net nutrition. How did workingclass families cope with war inflation? Probably, during the years 19151919, working-class families learned to substitute expensive sources of nutrients such as cereals and meat, with less expensive ones such as potatoes and rice. Regarding the Great Depression it should be remembered that Argentina recovered quite rapidly, as the conditions of relative prices and tariffs favored the development of domestic industry.

\section{REGIONAL DIFFERENCES}

Analysis of the data compiled by Juan S. López on the 1924 cohort of Argentine recruits reveals the existence of important differences in height between regions. The sample, the largest available so far $(\mathrm{N}=$ 142,105), includes 18-year-old recruits from all twenty-two provinces plus the capital, in a proportion similar to the distribution of the Argentine population in the 1914 Census (Salvatore 2000). In comparison with Santa Fé, the province with the tallest recruits, average heights in the poor provinces of the northwest, Jujuy and Salta, were 7.3 and 5.6 centimeters shorter ${ }^{49}$. If the standard of comparison is the Humid Pampa, then the recruits of Salta and Jujuy are 6.7 and 5.0 centimeters shorter; while the recruits from other poor provinces such as Catamarca, Neuquén and Tucumán were 3.1 and 3.7 centimeters shorter (see Table 2).

By this time ${ }^{50}$, the differences in net nutrition between the provinces of the Pampa region had been reduced significantly. Recruits born in Córdoba were approximately one centimeter shorter than the tall recruits from Santa Fe. The differences between the stature of recruits from the provinces of Buenos Aires and Entre Ríos and those of Santa Fe were even smaller. Outside the Pampa region (in the Interior), on the other hand, stature differences were still significant. A poor province such as La Rioja, occupying a position in the middle of the rank, had a mean average 2.8 centimeters taller than that of Salta and 4.5 taller than that of Jujuy. The contrast between the Pampa and the Interior was apparently still important. The first 6 places in the rank were occupied

48 If these campaigns (which centered on the registration of child workers) were effective, working-class families could generate more stature growth with the same budget.

49 For the group of provinces that included San Juan, Corrientes, Río Negro, Catamarca, Tucumán and Neuquén, such differences stood between 3.1 and 4.2 centimeters.

50 These recruits reached 2.5 years of age in 1926 . 
by the capital and the five provinces of the Pampa region ${ }^{51}$. The progress of the "Golden Age» had not been sufficient to reduce regional heterogeneity in human well-being.

We also found additional variation in nutrition and health conditions within the provinces. Table 3 ranks provinces according to the dispersion of their height distributions (measured by the C.V.). Chubut, with a difference of 13 centimeters between the «best» and the "worst» of its

TABLE 2

PROVINCES RANKED BY THEIR MEAN STATURE

(Recruits born in 1924) ${ }^{52}$

\begin{tabular}{|l|l|r|c|c|}
\hline Rank & \multicolumn{1}{|c|}{ Province } & $\begin{array}{c}\text { Mean } \\
\text { Stature }\end{array}$ & $\begin{array}{c}\text { Difference with } \\
\text { Santa Fe }\end{array}$ & $\begin{array}{c}\text { Difference with } \\
\text { Pampa region }\end{array}$ \\
\hline 1 & Santa Fé & 170.16 & 0 & 0.56 \\
2 & Santa Cruz & 169.8 & -0.36 & 0.2 \\
3 & Capital Federal & 169.65 & -0.51 & 0.05 \\
5 & Buenos Aires & 169.56 & -0.6 & -0.04 \\
6 & Entre Ríos & 169.46 & -0.7 & -0.14 \\
7 & Lórdoba & 169.2 & -0.9 & $6-0.4$ \\
8 & Formosa & 169.1 & -1.0 & $6-0.5$ \\
9 & Chaco & 167.05 & -2.11 & -1.55 \\
10 & Mendoza & 167.55 & -2.17 & -1.61 \\
11 & Misiones & 167.5 & -2.61 & -2.05 \\
12 & Santiago del Estero & 167.38 & -2.6 & -2.22 \\
13 & Chubut & 167.32 & -2.78 & -2.28 \\
14 & La Rioja & 167.32 & -2.84 & -2.28 \\
15 & San Luis & 167.31 & -2.84 & -2.29 \\
16 & San Juan & 167.06 & -2.85 & -2.54 \\
17 & Corrientes & 166.97 & -3.1 & -2.63 \\
18 & Río Negro & 166.79 & -3.19 & -2.81 \\
19 & Catamarca & 166.46 & -3.37 & -3.14 \\
20 & Tucumán & 166.21 & -3.7 & -3.39 \\
21 & Neuquén & 165.91 & -3.95 & -3.69 \\
22 & Salta & 164.51 & -4.25 & -5.09 \\
23 & Jujuy & 162.85 & -5.65 & -6.75 \\
\hline
\end{tabular}

Source: Salvatore 2000, based on J.S. López 1950.

51 Santa Cruz, the southernmost province of continental Argentina, is an anomaly.

52 These are crude averages, not controlled by regional variations in the composition of the sample. At first glance, these data present certain anomalies which are difficult to explain. The province of Santa Cruz appears among the tallest, close to the provinces of the Pampa region. The province of Chaco, producing cotton and wood under conditions of labor exploitation and poverty, appears close in the list to Mendoza, a richer province, where immigrants settled to cultivate vines under conditions of small-scale property and tenancy. 
TABLE 3

HEIGHT DIFFERENCES WITHIN EACH PROVINCE

(Departmental averages, recruits born in 1924)

\begin{tabular}{|l|c|c|c|c|c|}
\hline \multicolumn{1}{|c|}{ Province } & Maximun & Minimun & Range & Std. Dev. & C.v. \\
\hline Chubut & 172.36 & 158.96 & 13.4 & 3,98 & 0,0238 \\
Jujuy & 164.66 & 157.45 & 7.21 & 3,22 & 0,0198 \\
Salta & 167.87 & 158.82 & 9.05 & 3,11 & 0,0189 \\
La Pampa & 171.48 & 165.34 & 6.14 & 2,69 & 0,0159 \\
Río Negro & 167.69 & 162.74 & 4.95 & 2,59 & 0,0155 \\
Misiones & 169.48 & 162.69 & 6.79 & 2,47 & 0,0147 \\
Catamarca & 168.7 & 161.89 & 6.81 & 1,72 & 0,0103 \\
Formosa & 169.28 & 167.05 & 2.23 & 1,63 & 0,0097 \\
Neuquén & 167.72 & 162.79 & 4.93 & 1,55 & 0,0093 \\
Corrientes & 168.67 & 163.03 & 5.64 & 1,46 & 0,0087 \\
Córdoba & 170.87 & 165.3 & 5.57 & 1,4 & 0,0083 \\
Chaco & 170.34 & 166.60 & 3.74 & 1,34 & 0,0080 \\
San Juan & 168.38 & 164.06 & 4.32 & 1,29 & 0,0077 \\
La Rioja & 170.34 & 165.96 & 4.38 & 1,25 & 0,0075 \\
Santa Fe & 172.65 & 168.25 & 4.4 & 1,14 & 0,0067 \\
Entre Ríos & 171.32 & 167.19 & 4.13 & 1,1 & 0,0065 \\
Tucumán & 167.43 & 163.95 & 3.48 & 1,09 & 0,0066 \\
Buenos Aires & 172.82 & 166.74 & 6.08 & 1,08 & 0,0064 \\
Mendoza & 169.94 & 164.93 & 5.01 & 1,07 & 0,0064 \\
Sgo del Estero & 170.08 & 164.85 & 5.23 & 1 & 0,0060 \\
San Luis & 167.93 & 165.42 & 2.51 & 0,81 & 0,0048 \\
\hline
\end{tabular}

Source: Estimated from Salvatore 2000.

departments, is to be found at the head of this list. The provinces of the northwest (Salta and Jujuy) followed with dispersion ranges of 7 and 9 centimeters. Close to them were two poor provinces, Catamarca and Misiones (with ranges of 6.0 and 6.8 centimeters), but also two rich provinces, La Pampa and Buenos Aires. Apparently, internal differences in well-being are not directly associated with the wealth or poverty of provinces. The provinces of Santa Fe and Entre Rios, which we usually associate with a more egalitarian type of agrarian development (with smallscale farming and owner-operated farms), showed an intermediate level of regional dispersion (4.2 to 4.4 centimeters of difference) ${ }^{53}$.

The greatest inequality in heights was detected in the extreme north (Salta and Jujuy) and south (Chubut and Santa Cruz) of the country. In

53 Provinces with low income levels (Chaco, Tucumán, San Luis y Formosa) appeared to be quite "egalitarian» in terms of the internal distribution of average heights (dispersion of 2.2 to 3.7 centimeters). 
these regions, one finds a low degree of territorial integration - consequently, notable differences in the prices of food between departmentscombined with poor states, unable to implement public health policies of provincial scope. In the last six positions in the table, corresponding to provinces with low dispersion of heights, one finds a curious combination of rich and poor provinces. Entre Ríos and Buenos Aires have similar levels of inequality to Tucumán, Santiago del Estero and San Luis. In other words, provinces with closely-knit transportation systems, impressive urban development and greater wealth appear to be as «egalitarian» as provinces with few roads and railroads, smaller urban centers, poor sanitation infrastructures and lower per-capita income.

\section{INTRA-REGIONAL CONVERGENCE: THE CASE OF THE ARGENTINE NORTHWEST}

The cross-section data provided by López contained no information regarding the evolution of regional biological welfare. In order to estimate trends at a regional level we resorted to recruitment data for the cohorts 1916-1951 microfilmed by the Argentine Army. From this source, we took sufficiently large samples for the Northwestern region, defined as including the provinces of Santiago del Estero, Catamarca, Tucumán, Salta and Jujuy ${ }^{54}$. With a regression model, we estimated standardized mean heights at the provincial and departmental level for five benchmarks. We controlled for age, occupation, urban-rural condition, illiteracy, physical condition and special skills (Salvatore 2004b).

The results were quite remarkable. During the period 1916-1951 we found a clear process of convergence of biological welfare within the Northwest. The initial differences between the heights of santiagueños, tucumanos, catamarqueños and salteños decreased over time, finally becoming negligible. Only the province of Jujuy, which started converging in the period 1916-1934, still showed significant differences with the rest of the northwestern provinces by 1951. Table 4 and Figure 5 illustrate the process of intra-region convergence. As a whole, the Northwest grew 2.1 centimeters in stature between 1916 and 1951. However, the province with the tallest stature (Santiago del Estero) remained almost stagnant while the other three provinces caught up. Salta's catching-up experience was impressive: a growth of 4 centimeters during this period.

\footnotetext{
${ }^{54}$ For the initial and final years (1916 and 1951), two samples were taken $(\mathrm{N}=4,600)$ covering 44 departments of these five provinces. For the intermediate periods $(1929,1934$ and 1943) we took smaller samples $(\mathrm{N}=2,800)$ covering 28 departments.
} 
TABLE 4

EVOLUTION OF MEAN STATURE IN THE NORTHWEST

(Standardized averages)*

\begin{tabular}{|l|c|c|c|}
\hline \multirow{2}{*}{ Province } & \multicolumn{2}{|c|}{ Estimated Mean Heights } & \multirow{2}{*}{ Variation } \\
\cline { 2 - 3 } & $\mathbf{b . 1 9 1 6}$ & $\mathbf{b . 1 9 5 1}$ & \\
\hline Santiago del Estero & 167.47 & 167.97 & 0.50 \\
Tucumán & 165.78 & 168.09 & 2.31 \\
Catamarca & 165.94 & 167.63 & 1.69 \\
Salta & 163.01 & 166.99 & 3.98 \\
Jujuy & 161.44 & 164.39 & 2.95 \\
Northwest region & 165.12 & 167.23 & 2.11 \\
\hline
\end{tabular}

* 18-year-old unskilled laborers, literate, rural, physically apt for service. Source: Salvatore (2004b).

FIGURE 5

INTRA-REGIONAL CONVERGENCE IN THE ARGENTINE NORTHWEST

(Standardized averages, 18-year-old recruits)

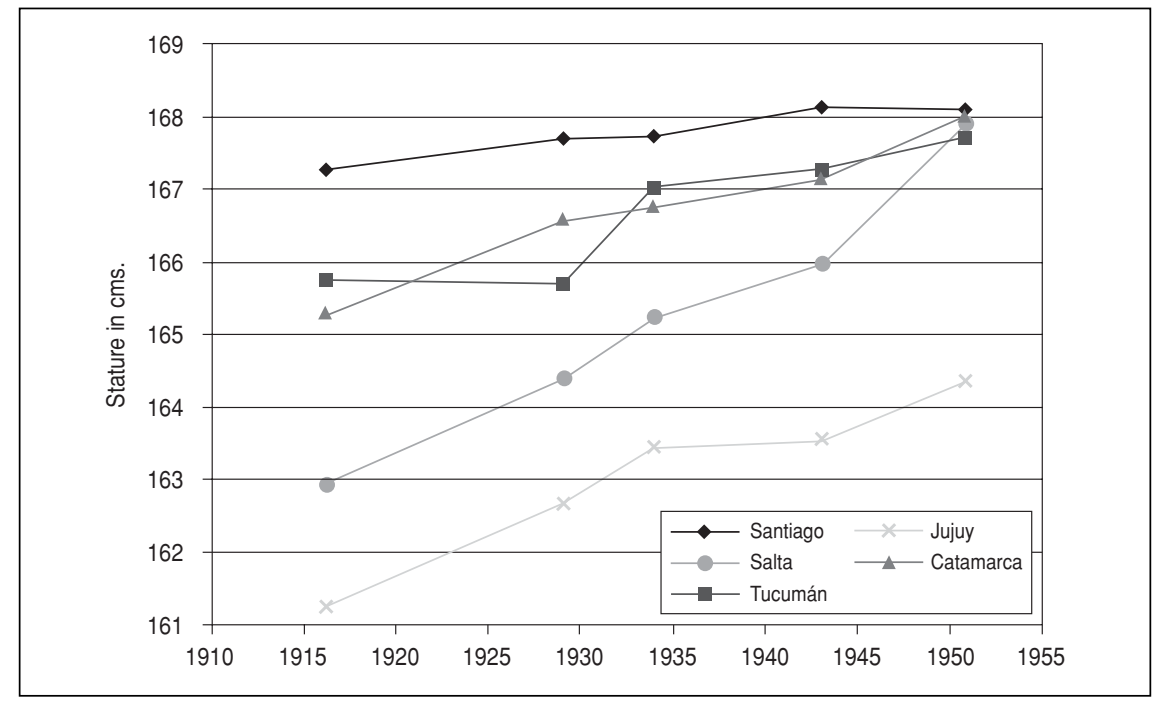

Source: Salvatore 2004b (Northwestern sample).

Convergence within the Northwest relates to the process of uneven regional development. The provinces with greatest stature growth (Salta and Jujuy) were areas which changed their productive specialization, becoming producers of sugar, incorporating new crops such as tobacco 
and beans and developing some of their valuable natural resources. In the case of Salta, the discovery and extraction of petroleum generated pockets of population settlement and investment. The provinces with little or no change in stature, Catamarca and Santiago del Estero, on the other hand, were those where productive structure changed little. Their economies were based upon peasant agriculture, the exploitation of forest resources and labor-intensive mining. Tucumán, an old sugar-producing area with the highest population density of the region, suffered recurrent economic crises during this period.

Convergence also took place at the departmental level. Comparing the evolution of the 28 districts of our sample, we found that those departments which grew most during this period were those that in 1915 had the lowest stature. The presence of $\beta$-convergence would indicate that more general and diffused factors, such as improvements in transportation, communications and sanitation, helped convert the Northwest into a more homogeneous region in terms of nutrition and health. This improvement, however, was insufficient for the Northwest to reach the levels of net nutrition of Buenos Aires or those of the Pampa region. Our estimates show that the gap between the Northwest and Buenos Aires remained within the range of 3.2 to 3.7 centimeters.

Stature differences associated with occupation and skills were significant, large and tended to grow with time. In the Northwest, illiterate recruits were one centimeter shorter than those who had basic writing and reading skills. In the 1951 cohort, employees were 1.8 centimeters taller than unskilled laborers. Students were more than 3 centimeters taller than unskilled laborers. In the Northwest too, differences in stature associated with socio-economic conditions were more persistent than differences associated with urbanization. Our preliminary results tend to discard factors usually considered highly relevant in the narrative of social and economic development of the region: out-migrations; the ethnic composition of the population; and the impact of sugar ingenios. Regression results showed that neither the proportion of Bolivian immigrants nor the presence of net out-migration was relevant in determining average heights. We also found that the evolution of stature in sugar-growing areas did not differ significantly from areas with a predominant peasant economy.

\section{HEIGHT AND INDUSTRIALIZATION: THE BUENOS AIRES INDUSTRIAL BELT}

In a recent essay I used the height of recruits to evaluate the welfare impact of industrialization in the 1930s and 1940s. (Salvatore forthcoming) The sample $(\mathrm{N}=15,500)$ included 18-year-old recruits from seven 
of the 19 districts of the Buenos Aires industrial belt («Conurbano bonaerense») for all even years between 1916 and 1950. The districts chosen were among the ten most important industrial areas of the country in the 1935 Census, all areas with high population density ${ }^{55}$. As a control, we took a sample of interior migrants residing in this area (12 percent), and another sample of residents of the city of La Plata. Most of the recruits had been born in urban areas, were literate, and had modern skills (such as driving motor vehicles). Workers made up 73 percent of the sample, while the rest were students, farmers and merchants.

This new evidence shows that the natives of the industrial belt grew 2.1 centimeters on average between 1918 and 1952 (the data is presented with a 2-year lead from birth). Surprisingly, most of this growth took place before Juan Perón became President. In fact, the stature of the average recruit in 1950 seems to have been almost the same as that of 1938 (birth cohort +2$)$. This is related to the second important finding: a fall in mean stature during the period 1940-1948. This finding underscores the difficulties that war-time scarcities of fuel and food might have caused for working-class families and casts doubt on the diffusion and scope of Peronist welfare and wage policies. The failure of price-control policies during the postwar period (1945-48) might have placed stress on the budgets of informal workers and laborers.

The estimates of average height in the industrial belt reinforce our previous finding, that during 1925-1940 urban residents experienced the greatest gains in biological welfare. Import-substituting industrialization, under conditions of mass migration and rapid urban growth, generated an improvement in net nutrition. In the face of this evidence, we need to re-think the social policies of Peronism in comparison with those of the conservative administrations of the 1930s. The greatest falls in infant mortality rates, in the capital city as well as in the Conurbano, were achieved in the late 1920s and in the 1930s. Improvements in sanitation lowered the mortality caused by gastro-intestinal infections, an improvement not achieved by the interior provinces until much later. Migrant workers who came to the Buenos Aires industrial belt in the 1930s found a city already enjoying the benefits of sanitation improvements. Rapid urban growth and industrialization provided employment to the newcomers, while the prices of food were in decline. Due to the closing of foreign markets there was over-production of meat and grain.The implications of Figure 6 are clear: the best years of Peronist income redistribution and rapid industrial growth (1945-49) coincided with a period of declining average stature in the industrial cities surrounding the capital, a decline which started earlier during the

\footnotetext{
55 An average of 3,600 inhabitants per $\mathrm{km}^{2}$ in the 1960 census.
} 
FIGURE 6

STATURE GROWTH IN THE BUENOS AIRES INDUSTRIAL BELT

(Standardized means, two-year lead)

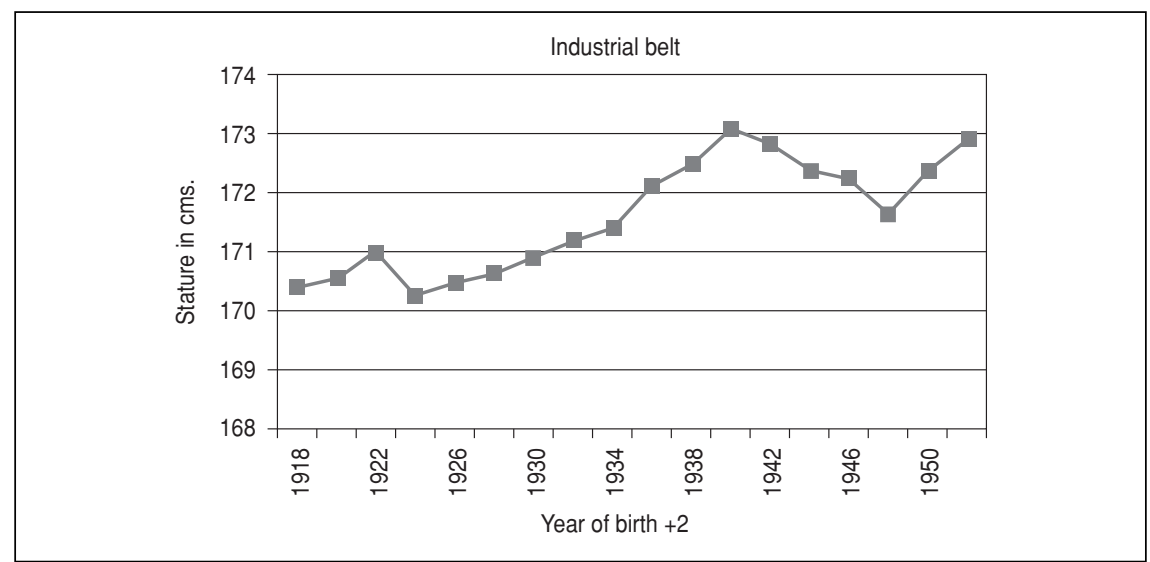

Source: Salvatore (2005)

(average all recruits: weights: 0.40 unskilled laborers, 0.35 skilled workers; 0.25 employees)

Second World War. This is an anomaly or puzzle as important as that found for the "Golden Age». How can this anomaly be explained? It is likely that during the Peronist years, migrants came in such great numbers that they depressed wages, creating a divided or dual labor market. While some workers joined industrial unions, enjoyed social benefits and resided in or near the capital, many joined the casual labor market, enjoyed no social benefits, and resided in districts far from the city.

In a recent paper, we have estimated a proxy for the malnutrition rate in the Conurbano calculating the percentage of recruits with a stature below the average stature minus one standard deviation. This is what the United Nations considers «moderate stunting». The results of this calculation are presented in Figure 7 (data presented with a two-year lead from birth). In the 1930s, the overlapping effects of urban sanitation, industrialization and low food prices generated the most important drop in the estimated rate of malnutrition. In comparison to the late $1920 \mathrm{~s}$ and 1930s, the war period appears as a time of trouble, marked by inflation, shortages of food and fuel and worsening sanitary conditions. Diarrhea had a strong impact on the health of babies in 1942-43, this situation stabilizing during the following years. Early Peronism (at least until 1952) failed to reverse this situation. Under conditions of mounting inflation, it seemed difficult to achieve further declines in the rates of malnutrition. These estimates need greater refinement and confirmatory 
FIGURE 7

ESTIMATED MALNUTRITION RATE 1916-1950

(Calculated with fixed benchmark)

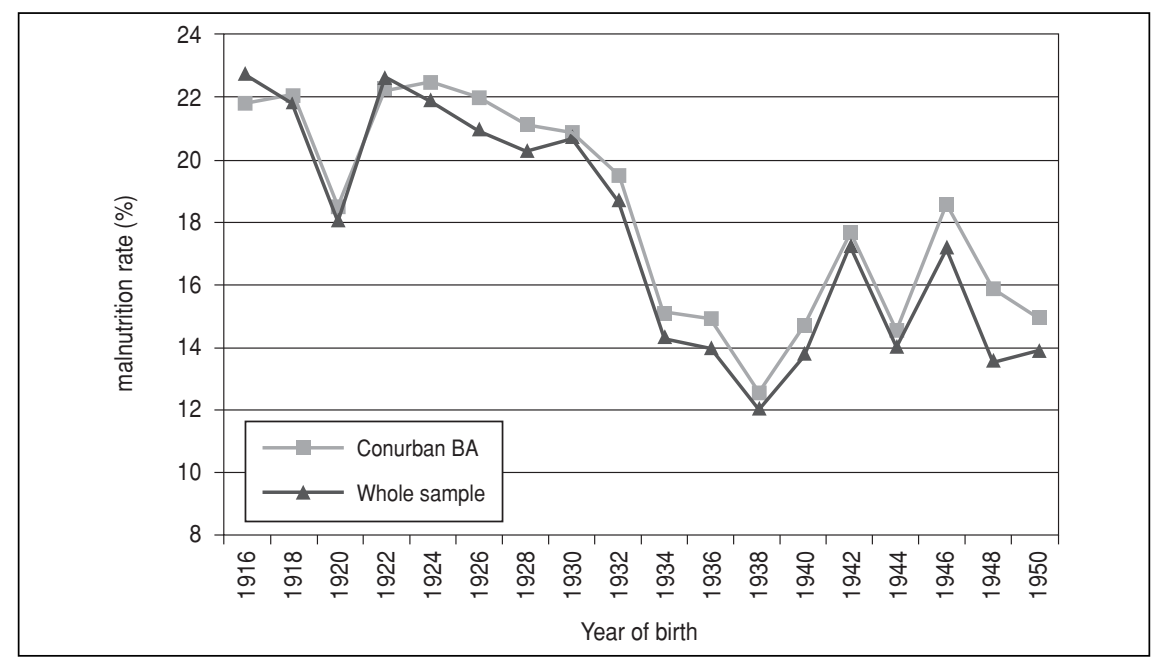

Source: Salvatore, «Stature Growth in Industrializing Argentina».

*benchmark = average height minus one standard deviation

**The whole sample includes provincial migrants.

evidence. However, they should caution us against being too optimistic about the impact of Peronist welfare policies. These policies probably had beneficial effects on the health and nutrition of the unionized working-class, but this did not necessarily extend to those who entered informal labor markets and resided in the industrial belt.

Social and economic differences between recruits were more persistent than assumed. More inclusive social policies during Peronism did little to change inequalities in access to nutrients and public health. Interior migrants were and continued to be 1.4 to 1.5 centimeters shorter than those born and raised in the Conurbano. Height inequalities by occupation increased clearly. The advantage of clerical employees over unskilled laborers rose from 1.4 to 1.6 centimeters between 1916-32 and 1934-50. The advantage of students over unskilled workers rose from 2.6 to 3.1 centimeters during the same period. True, there was a greater equality in the distribution of stature among industrial districts. Before 1932, recruits from Morón, La Plata and Quilmes were much taller than those from the other districts. After the process of industrialization (1934-50), the differences reduced to less than one centimeter. This evidence also points in the direction of intra-region convergence, but the reasons for this tendency are at this point unclear. 
The Buenos Aires industrial belt presents a counter-example of what has been registered in the literature as the problem of «urban disamenities». The coefficient for urban condition proved not to be significant in this case. The migrants born in rural areas moved to satellite cities in which the risk of disease was lower than in their provinces of origin. By residing in areas surrounding the city, these migrants avoided paying the rising cost of rent in the capital while the government subsidized their transportation costs.

\section{NUTRITION AND HEALTH IN THE LONG-RUN}

As it was not possible to present a consistently homogenous series for the whole period covered in this essay, I have examined fragments of evidence on heights available for different periods and referring to conditions in the capital city, in the province of Buenos Aires and the country as a whole. My objective has been to present the findings obtained so far of a broader and far-reaching research project concerning the history of nutrition, health and welfare in modern Argentina. In this last section, I present a composite or summary of these results in an attempt to provide a general framework within which the long-run evolution of biological welfare in Argentina could be examined.

Anthropometric history offers the possibility of re-visiting the economic and institutional history of Argentina. New measurements of average heights based on records of recruits, prisoners and soldiers allow us to reconsider some traditional hypotheses regarding the major periods into which Argentine economic growth is divided. Our investigation suggests that the late colonial period (ca.1790-1805) was characterized by a lack of food for peasants and rural laborers. This situation was reversed in the post-independence era due to a multiplicity of factors related to institutional changes, population movements and the dynamics of military mobilization. As a result, the children of the 1820s and 1830s grew taller than the children born in the 1790s and 1800s. During the era of «liberal progress»(1850-1880), estimated stature shows that the expansion of wool and cattle-exports did not affect the biological well-being of the poor inhabitants of the Pampa region. Prisoners from the rural Buenos Aires region born in the 1850s had almost the same stature as those born in the 1880s. Those residing in the city of Buenos Aires - the city which retained the control of custom duties and, hence, could afford improvements in public health and education- achieved some gains in stature ${ }^{56}$.

\footnotetext{
56 Again, this result needs confirmation.
} 
In the following period (1880-1940), standardized estimates for average heights (generated from prison records) show a stagnation of stature growth for the population in the lower strata of the occupational hierarchy. Stature decreased significantly after the crisis of 1890-93, only to recover slowly during the 1900s and the 1910s, not reaching the level of the 1880s until the mid 1920s. Only in the 1930s was there a clear increase in average stature and this improvement was associated with intensified industrialization. Using evidence from prisons or recruit data, we reach the same conclusion: export-led growth did not produce any significant improvement in the biological well-being of workers. In terms of rates of growth of exports and income, the Argentine Pampas was a successful economy integrated in the world market through flows of goods (beef and grain), capital, migrants and technology. It was also, however, an economy suffering from high social inequality, only partially addressed by the provision of free elementary education. High wages attracted European immigrants, but many of them complained about the high cost of food (competitive with exports) and rent (the supply of housing could not keep up with the demand). Not surprisingly, remittances to their home countries, an indicator of savings capacity, were limited as compared with those sent by Italian immigrants residing in New York ${ }^{57}$.

Estimates of height taken from the Patricios Battalion reveal a littleknown dimension of agro-export growth during the "Golden Age»: the presence of a situation of nutrition stress at the core of the export economy, during the decade of most rapid economic growth (1901-1910). The paradox of nutritional problems in a food-rich export economy may not be surprising to an observer of contemporary Argentina ${ }^{58}$, but it is clear that the traditional economic history of Argentina had underestimated the risk of malnutrition in a food-exporting economy. Although of small magnitude and confined to the interior, the fall in the average stature of unskilled native laborers indicates problems of regional and social inequality associated with this type of development. Mass immigration pushed nominal wages down and raised the prices of food and rent ${ }^{59}$. In combination with the spread of unregulated child labor and crowded housing conditions in cities, this prevented the gains of exportled growth from leading to better nutrition and health conditions for the laboring poor.

57 See Baily (1999).

58 Since the crisis of 2002, the Argentine boom in the export of food commodities (soybean and corn) has coincided with inflation in food prices and high poverty rates.

59 Spanish and Italian immigrants continued to arrive as long as the nominal wage-gap between Argentina and the two Mediterranean countries remained large enough. This wagegap declined significantly in the 1920 s causing a decline in figures of net immigration and anticipating its dramatic fall during the Great Depression. 
In contrast, the literature has underestimated the quality of the growth of the interwar period, the truth being that this period produced strong and sustained growth in average stature. Part of this advance in biological well-being can be associated with the lifting of obstacles to human growth: the regulation of child labor, greater efficacy in the control of infectious diseases and the slowing down of European immigration ${ }^{60}$. But the improvement in the condition of children in the 1920s and 1930s was also related to new state policies which protected abandoned children, promoted a more diversified diet and distributed milk among school children.

Concerning the regional dimension of development and welfare, our estimates confirm the suspicion of contemporary intellectuals and politicians that there were two Argentinas: one healthy and prosperous in the Pampa region; the other unhealthy and under-nourished in the interior provinces ${ }^{61}$. Though the state tried to reduce these differences, chiefly via investment in elementary education and transportation infrastructures, our estimates suggest that the gap between the Pampas and the Interior was maintained well into the 1940s.

Economic growth in the post First World War period (our data covers the period 1916-1951) also produced a convergence of stature within regions. This was the case for the Argentine Northwest, one of the poorest regions in the country at the beginning of the $20^{\text {th }}$ century. The expansion of transportation, the diversification of production, the diffusion of price information and the sustained effort to eradicate endemic diseases resulted in long-term improvements in biological welfare. The difference in stature between the Littoral provinces and the Northwest remained unchanged until 1950. While the factors which conditioned this growth are not yet fully understood, the finding is in itself quite important as it shows that a region subjected to intense outmigration and with relatively little investment of capital can have a significant intra-regional convergence in conditions of nutrition and health.

Preliminary estimates of heights of recruits from Conurban Buenos Aires confirm the beneficial effect of import-substituting industrialization during the 1930s. Stature grew significantly during this period, in spite of massive internal migrations and their depressing effects upon wages. Apparently, migrant workers did not have to pay an «urban

\footnotetext{
${ }^{60}$ It is also feasible that parents of working-class children started to give more importance to elementary education at the cost of reducing the income generated by children's work.

${ }^{61}$ Alejandro Bunge and Alfredo Palacios were perhaps the most salient figures to put forward this view.
} 
penalty» for their decision to move to the industrial belt surrounding Buenos Aires. Lower infant mortality rates, the result of improvements in sanitation and lower food prices (due in part to the impact of the Great Depression), made this result possible. However, for the period of the Second World War, the biological standard of workers in the Conurbano fell, for reasons that are not clear at this point. Our estimates indicate that the improvement in living conditions brought about by the first Peronist administration might have been limited to the unionized workforce. Apparently, the impact of Peronist social policies on the bodies of children was more modest and later than suspected.

Figure 8 assembles the different series examined until now, generating a composite view of the long-run evolution of stature in Argentina. The estimates prior to 1850 have been removed because their comparability with 20 th century data is problematic. The data refer mostly to conditions prevailing in Buenos Aires province and its capital city, only two of the series (recruits of the Patricios Battalion and prisoners 2) including migrants from the Interior. This composite picture -including as it does series of mean standardized heights as well as crude meansshould be treated with caution. It is intended merely to give a sense of direction and proportion in the growth of average stature. According to this heterogeneous composite picture, it is clear that Buenos Aires pro-

FIGURE 8

LONG-RUN EVOLUTION OF STATURE, BUENOS AIRES 1850-1950

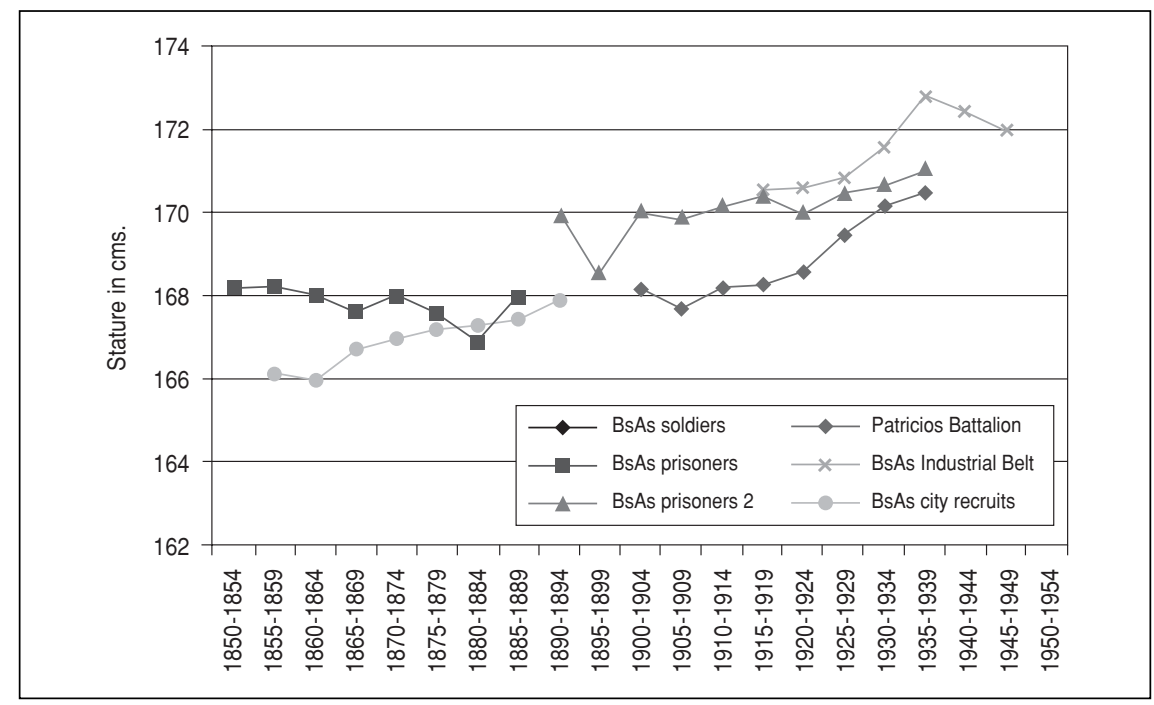


vince, and probably also the Littoral provinces, experienced a moderate increase in stature in the century that followed its full incorporation into the world market ${ }^{62}$. More importantly, most of this growth was achieved after 1914-18 and before the rise to power of Peronism (1945). This generalization should lead to a reconsideration of the traditional views of the economic history of Argentina, in particular, the notions that the period 1880-1914 was a "golden age», while the period 1919-1939 was one of "retardation» or "delay». In terms of biological welfare, there is sound evidence that the reverse was the case: workers in particular fared better during the so-called "great delay» than during the "golden age».

In this tentative assessment, the well-being of «Argentines» in the long-run compares favorably with that of Mexicans for the period 18501950, as estimated by López Alonso (2006), but is far less impressive than Italians before 1950 (Arcaleni 2006) and other European countries in the late 19 th and early 20 th centuries.

\section{REFERENCES}

Adelman, J. (1999): Republic of Capital: Buenos Aires and the Legal Transformation of the Atlantic World. Stanford: Stanford University Press.

Amaral, S. (1998): The Rise of Capitalism on the Pampas: The Estancias of Buenos Aires, 1785-1830. Cambridge: Cambridge University Press.

ARCALENI, E. (2006): "Secular trend and regional differences in the stature of Italians, 1854-1980». Economics and Human Biology 4, pp. 24-38.

BAILY, S. L. (1999): «Inmigrants in the lanol of promise: italians in Buenos Aires and New York city, 1870 to 1912». Cornell University Press, London.

BAssino, J. P. (2006): «Inequality in Japan (1892-1941): Physical stature, income and health». Economics and Human Biology 4, pp. 62-88.

BATEN, J. (2000): «Economic development and the distribution of nutritional resources in Bavaria, 1787-1839». Journal of Income Distribution 9, pp. 89-106.

Bogin, B. and KeEP, R. (1998): «Eight Thousand Years of Human Growth in Latin America: Economic and Political History Revealed by Anthropometry», in J. Komlos and J. Baten, eds., The Biological Standard of Living in Comparative Perspective. Stuttgart: Franz Steiner Verlag, pp. 268-293.

Brinkman, H. J., DrukKer, J. W., and Slot, B. (1998): «Height and Income: A New Method for the Estimation of Historical National Income Series». Explorations in Economic History 25, pp. 227-264.

Brown, J. C. (1979): A Socioeconomic History of Argentina, 1776-1860. Cambridge: Cambridge University Press.

\footnotetext{
62 At most, this growth could be in the range of 4 to 5 centimeters From 166-168 centimeters in the mid-1850s, it reached a level of 171-173 centimeters by the early 1940s. This comparison perhaps overestimates the growth in the biological well-being of workers. Comparing only the two series of prisoners of Buenos Aires province, the rise in stature is reduced to less than 3 centimeters, most of this improvement achieved after 1914.
} 
COATSWORTH, J. (1993): «La independencia latinoamericana: hipótesis sobre los costes y beneficios», in L. Prados and S. Amaral, eds., La independencia americana: consecuencias económicas, Madrid: Alianza.

Cortes Conde, R. (1979): El progreso argentino 1880-1914. Editorial Sud Americana, Buenos Aires.

Coelho, P. R., and McGuiRe, R. (2000): «Diets versus Diseases: The Anthropometrics of Slave Children». Journal of Economic History, 60 (1), pp. 232246.

Coll, S. (1998): «The Relationship between Human Physical Stature and GDP (Some Experiments with European Time Series)», in The Biological Standard of Living in Comparative Perspective, pp. 384-407.

Di Tella, G., and Zymelman, M. (1971): Las etapas del desarrollo económico argentino. Paidos, Buenos Aires.

Floud, R., and WachteR, K. (1982): «Poverty and Physical Stature: Evidence n the Standard of Living of London Boys, 1770-1870». Social Science History 6, pp. 422-452.

Floud, R., Wachter, K., and Gregory, A. (1990): Height, Health and History. Nutritional Status in the United Kingdom, 1750-1980. Cambridge: Cambridge University Press.

FogeL, R. W. (1987): «Nutrition and the Decline in Mortality since 1700: Some Preliminary Findings", in Long-term Factors in American Economic Growth, S. L. Engerman and R.E. Gallman, eds. Chicago: University of Chicago Press, pp. 439-555.

- (1994): «Economic Growth, Population Theory, and Physiology: The Bearing of Long-Term Processes on the Making of Economic Policy». The American Economic Review, 84 (3), pp. 369-395.

Fogel, R. W., Engerman, S. L., and Trussell, J. (1982): «Exploring the Uses of Data on Height: The Analysis of Long-Term Trends in Nutrition, Labor Welfare, and Labor Productivity». Social Science History 6, pp. 401-421.

Gallo, E. (1984): La pampa gringa. La colonización agrícola en Santa Fe (18701895), 2nd edition. Buenos Aires: Editorial Sudamericana.

GARAVAGLIA, J. C. (1995): «Precios de los productos rurales y precios en la campaña de Buenos Aires». Boletín del Instituto de Investigaciones Históricas Emilio Ravignani 11, pp. 65-112.

Gelman, J. (1996): «Unos números sorprendentes. Cambio y continuidad en el mundo agrario bonaerense durante la primera mitad del siglo XIX». Anuario IEHS 11, pp. 123-145.

Godoy, R., et al (2005): «Human Capital, Wealth and Nutrition in the Bolivian Amazon». Economics and Human Biology 3, pp. 139-162.

Guntupalli, A. M., and Baten, J. (2006): «The development of inequality of heights in North, West, and East India 1915-1944». Explorations in Economic History 43, pp. 578-608.

IrIgoin, M. A. (2000): «Inconvertible Paper Money, Inflation and Economic Performance in Early-Nineteenth-Century Argentina». Journal of Latin American Studies 32, pp. 333-359.

Johnson, L. L. (1994): «Distribution of Wealth in Nineteenth-Century Buenos Aires Province», in The Political Economy of Spanish America in the Age of Revolution, 1750-1850, K. J. Andrien and L. L. Johnson, eds. Albuquerque: University of New Mexico Press. 
Komlos, J. (1987): «The Height and Weight of West Point Cadets: Dietary Change in Antebellum America». Journal of Economic History 47 (4), pp. 897-927.

- (1989): Nutrition and Economic Development in the Eighteenth-Century Habsburg Monarchy. An Anthropometric History. Princeton: Princeton University Press.

- ed. (1995): The Biological Standard of Living on Three Continents. Further Explorations in Anthropometric History. Boulder, Co.: Westview Press.

- (1996): «Anomalies in Economic History: Toward a Resolution of the «Antebellum Puzzle». Journal of Economic History, 56 (1), pp. 202-214.

Komlos, J., and BATEN, J. eds. (1998): The Biological Standard of Living in Comparative Perspective. Stuttgart: Franz Steiner Verlag.

- (2004): «Looking Backward and Looking Forward: Anthropometric Research and the Development of Social Science History». Social Science History 28 (2), pp.191-210.

Komlos, J., and Lauderdale, B. (2007): «Underperformance in Affluence: The Remarkable Relative Decline in US Heights in the Second Half of the TwentiethCentury». Social Science Quarterly 88 (2), pp.283-305.

Lopez-Alonso, M. (2007): "Growth with Inequality: Living Standards in Mexico, 1850-1950». Journal of Latin American Studies 39, pp. 81-105.

Margo, R., and Steckel, R. H. (1982): "The Height of American Slaves: New Evidence on Slave Nutrition and Health», Social Science History 6, pp. 516-538.

Moradi, A., and BATEN, J., (mimeo): «Inequality in Sub-Saharan Africa 1950-1980: Estimates and New Results» University of Tubingen.

Newland, C. (1998): "Exports and Terms of Trade in Argentina, 1811-1870». Bulletin of Latin American Research 17 (3), pp. 409-416.

Saвato, H. (1990): Agrarian Capitalism and the World Market: Buenos Aires in the Pastoral Age, 1840-1890. Albuquerque: University of New Mexico Press.

Salvatore, R. D. (1998a): "Heights and Welfare in Late-Colonial and PostIndependence Argentina», in The Biological Standard of Living in Comparative Perspective, J. Komlos y J. Baten, eds. Stuttgart: Franz Steiner Verlag, pp. 97-121.

- (2000): «The Regional Dimension of Biological Welfare: Argentina in the 1920s». Buenos Aires. Instituto y Universidad Torcuato Di Tella, Serie Seminarios 2/2000.

- (2003): Wandering Paysanos. State Order and Subaltern Experience in Buenos Aires during the Rosas Era. Durham and London: Duke University Press.

- (2004a): "Stature Decline and Recovery in a Food-Rich Export Economy: Argentina 1900-1934». Explorations in Economic History 41 (3), pp. 233-255.

- (2004b): «Stature, Nutrition, and Regional Convergence. The Argentine Northwest in the Fist Half of the Twentieth Century». Social Science History 28 (2), pp. 297-324.

- (2004c): «Biological Welfare in the Argentine Pampas. The Height of Prisoners in Buenos Aires province, 1888-1939», paper presented at the Second International Conference on Economics and Human Biology, Munich, June 25, 2004. Unpublished.

- (forthcoming): «Better-off in the Thirties. Welfare Indices for Argentina, 19001940», in The Standards of Living in Latin American History, R. Salvatore, J. Coatsworth, and A. Challú, eds. Cambridge, Mass.: Harvard University Press.

- (2005): «Stature Growth in Industrializing Argentina: The Buenos Aires Industrial Belt 1916-1950», paper presented at the Workshop 
"Anthropometrics, Markets and Disease in the Historical Standard of Living», Keio University, Japan, 22-25 March 2006. Unpublished.

Salvatore, R. D., y Baten, J. (1998b): "A Most Difficult Case of Estimation: Argentinian Heights 1770-1840», in The Biological Standard of Living in Comparative Perspective, pp. 90-96.

Salvatore, R. D., y Newland, C. (2003): «Between Independence and the Golden Age: The Early Argentine Economy», in A New Economic History of Argentina en G. della Paolera and A.M. Taylor, eds. Cambridge and New York: Cambridge University Press, pp. 19-45.

Schultz, T. P. (2003): «Human Capital, Schooling and Health». Economics and Human Biology 1, pp. 207-221.

Sen, A. (1985): Commodities and Capabilities. Amsterdam and New York: NorthHolland.

Steckel, R. H. (1979): «Slave Height Profiles from Coastwise Manifests». Explorations in Economic History 16, pp. 363-380.

- (1995): «Stature and the Standard of Living». Journal of Economic Literature 33, pp. 1903-1940.

- (1998): «Strategic Ideas in the Rise of the New Anthropometric History and Their Implications for Interdisciplinary Research». Journal of Economic History, 58 (3), pp. 803-821.

SteCKel, R., and Floud, R., eds. (1997): Health and Welfare during Industrialization. Chicago: University of Chicago Press.

Tandeter, E. (1991): "Crisis in Upper Peru, 1800-1805». Hispanic American Historical Review 71 (1), pp. 35-71.

Voth, H. J., and Leunig, T. (1996): «Did Smallpox Reduce Height? Stature and the Standard of Living in London 1770-1873». Economic History Review, 49 (3), pp. 541-560. 